\title{
Treatment's Effect on Mechanical Properties of Kenaf Bast/Natural Rubber Latex Foam
}

\author{
Nurul Jannah Sallehuddin and Hanafi Ismail *
}

Non-treated and silane-treated kenaf bast/natural rubber latex foam (NRLF) were prepared using the Dunlop method at different filler loading $(0,3,5$, and 7 pphr). The properties were investigated in terms of mechanical properties, tensile, compression, hardness, and swelling behavior. Fourier transform infrared spectroscopy (FTIR) and scanning electron microscopy (SEM) were used to characterize kenaf bast/NRLF. With the modulus at $100 \%$ elongation (M100), the compression strength and hardness showed increments in value with increments of kenaf loading. However, different results showed in tensile strength, elongation at break, swelling percentage, and recovery percentage, which decreased at higher filler loading. Silane-treated kenaf bast/NRLF showed higher value in all properties except for elongation at break, swelling, and recovery percentage. The improvement of properties was supported by SEM surface morphological studies that showed better adhesion between the rubber matrix and kenaf filler.

Keywords: Silane treatment; Kenaf bast; Natural rubber latex; Foam

Contact information: School of Materials and Mineral Resources Engineering Campus, Universiti Sains Malaysia, 14300 Nibong Tebal, Pulau Pinang, Malaysia; *Corresponding author: ihanafi@usm.my

\section{INTRODUCTION}

The Hevea brasiliensis tree is the source of natural rubber latex (NRL), which is an important material for manufacturing (Ramasamy et al. 2013). Besides being tremendously economic, natural rubber latex also is a natural product with strategic importance (Roslim et al. 2012). Natural rubber latex is common in the production of extruded threads, dipped goods, adhesives, carpet-backing, and molded foams (Karim et al. 2018). Concerning the natural rubber (NR), the utilization of natural rubber latex in liquid form is the most wellknown and traditional way to produce foams. Chemical stabilization, which can be accomplished through the addition of ammonia, is necessary due to the colloidal nature of latex (Ariff et al. 2008). The NR latex foam (NRLF) is one of the applications of NR latex. The synthesis process of NR latex foam has been carried out according to the common Dunlop manufacturing method. Since ancient times, the Dunlop manufacturing method has been the most reliable and economical method of making NRLF (Rathnayake et al. 2014).

Recently there has been widespread research interest in the development of polymer composites using green natural bio-fillers. This is because of the advantages possessed by a natural fiber composite, such as being lightweight, low cost, and having a high modulus and specific strength, along with being renewable in nature, a comparative advantage over synthetic fiber that is disposable and recyclable (Abdul Wahab and Husseinshah 2018). Saheb and Jog (1999) reported that one of the major advantages of using natural fibers is higher specific properties when desired properties are needed. Saheb and Jog (1999) discussed that specific modulus of natural fibers are better than glass fibers, which lead to 
comparable mechanical properties to those of glass fiber.

Flax, kenaf, hemp, and jute are bast cellulosic fibers that have an appealing potential as reinforcements in composites (Huo et al. 2013). One of the natural fibers, kenaf, has been used as a reinforcement in polymer matrix composites (Hao et al. 2018). Kenaf (Hibiscus cannabinus L., family Malvaceae) has been intensively planted to replace tobacco plantations in Malaysia (Kuthi et al. 2018). As one of the natural fibers, kenaf is mostly used because of its capability of fast growth, which delivers a large volume of raw material in a short period of time (Kamal 2014).

Lacking interfacial adhesion between the natural fiber fillers and polymer matrix is one of the potential drawbacks in producing good biocomposites (Lee et al. 2009). The increment of hydrophilicity of fiber due to the large presence of hydroxyl groups in cellulose leads to incompatibility with hydrophobic polymer matrices that affect the strength of interfacial adhesion between fiber and matrix, resulting in low mechanical properties and performance of the composites (Huo et al. 2013). To overcome this problem, several methods of chemical modification by treatment have been identified and succeed at enhancing the fiber-matrix interface, such as alkali treatment, acetylation, silane treatment, and nucleation (Tran et al. 2014). In previous work, Ismail et al. (2001) reported that the incorporation of a silane coupling agent, 3-aminopropyl triethoxysilane (3-APE), improved tensile and water absorption properties on white rice husk ashpolypropylene/natural rubber composites, indicating that the use of the coupling agent enhances the filler-matrix interaction. Karim et al. (2018) studied the improvement of tensile properties and thermal stability of kenaf-filled NRLF by alkaline treatment. The results showed that tensile strength increased approximately $18 \%$ while elongation at break increased approximately $21 \%$ for treated samples. For thermal stability, the result showed an increment in value of approximately $10 \%$ for treated samples.

To the best of our knowledge, no study has reported on the use of coupling agent in NRLF. Thus, in this study, silane treatment was chosen to improve the interfacial adhesion between kenaf bast filler with NRL matrix of foam. Bis(triethoxysilypropyl)tetrasulfide (Si-69) as coupling agent was used in this work. The goal was to study the effect of silane treatment on mechanical and morphology properties of kenaf bast-filled foams. Improvement in tensile, compression, hardness and swelling properties which supported with characterization of FTIR and surface morphology proved the effectiveness of silane as coupling agent in kenaf bast/NRLF.

\section{EXPERIMENTAL}

\section{Materials and Formulation}

Table 1 exhibits the formulation used in this study. Bast kenaf fibres were dried, ground, and sieved into an average particle size of $70 \mu \mathrm{m}$. Zarm Scientific \& Supplies Sdn. Bhd. Bukit Mertajam, Malaysia was the supplier for most of the materials, including high ammonia (HATZ)-type NR latex, sulphur, antioxidant, potassium oleate, zinc diethyldithiocarbamate (ZDEC), zinc 2-mercaptobenzhiozate (ZMBT), zinc oxide, diphenylguanidine (DPG), and sodium silicofluoride (SSF). Kenaf bast was supplied by the National Kenaf and Tobacco Board, Kota Bharu, Malaysia. Bis(triethoxysilylpropyl)tetrasulfide (Si-69) as coupling agent was supplied by Bayer (M) Ltd., Leverkusen, Germany. 
Table 1. Kenaf Bast/Natural Rubber Latex Foam Formulation

\begin{tabular}{|c|c|c|}
\hline \multirow{2}{*}{ Ingredients } & \multicolumn{2}{|c|}{ Formulation } \\
\cline { 2 - 3 } & Total Solid Content (TSC\%) & Parts per Hundred Rubber (pphr) \\
\hline HA Latex & 60 & 100 \\
\hline Sulphur & 50 & 2.2 \\
\hline Antioxidant & 50 & 1 \\
\hline Potassium Oleate $^{*}$ & 20 & 0.5 \\
\hline ZDEC $^{1}$ & 50 & 0.9 \\
\hline ZMBT $^{2}$ & 50 & 3 \\
\hline Zinc Oxide & 50 & 0.3 \\
\hline DPG $^{3}$ & 40 & 1.2 \\
\hline SSF $^{4}$ & 25 & $0 / 1 / 3 / 5 / 7$ \\
\hline Kenaf Bast & - &
\end{tabular}

${ }^{*} \mathrm{TSC} \%$ - percentage by weight of the whole, which is non-volatile at definite temperature; ${ }^{1}$ zinc diethyldithiocarbamate; ${ }^{2}$ zinc 2 -mercaptobenzhiozate; ${ }^{3}$ diphenylguanidine; ${ }^{4}$ sodium silicofluoride

\section{Sample preparation}

The required amount of high ammonia latex concentrate (HATZ) was filtered and measured as shown in Table 1. Then, using a mechanical stirrer, the HATZ was stirred for approximately $10 \mathrm{~min}$ at $100 \mathrm{rpm}$. After $10 \mathrm{~min}$, sulphur (vulcanizing agent), ZMBT, and ZDEC (accelerator) were slowly added into the mixture for approximately 15 min, followed by the kenaf bast addition with continuous stirring for approximately $1 \mathrm{~h}$. Potassium oleate (foaming agent) was slowly added into the NRLF compound and then matured for $6 \mathrm{~h}$ at room temperature with a continuous stirring speed of $100 \mathrm{rpm}$. After 6 $\mathrm{h}$ of continuous stirring, the NRLF compound underwent the foaming process. Using a stand mixer (Kenwood, kMix, Havant, England) the NRLF compound was beaten intensively for $5 \mathrm{~min}$ until the volume was increased up to three times the initial volume. The foaming process was performed at speed level of 6 until the desired volume was achieved, then the speed was lowered to obtain a fine and even foam. Next, $\mathrm{ZnO}$ and DPG as primary gelling agents were added for 1 min followed by the addition of a secondary gelling agent, SSF, for approximately $15 \mathrm{~s}$. The un-gelled mixture was formed and quickly poured into an aluminium mold to obtain the desired shape and gelling process was completed by leaving the mixture at an ambient temperature for $3 \mathrm{~min}$. The curing process of gelled foam was then performed in an oven at $105^{\circ} \mathrm{C}$ for $2 \mathrm{~h}$. After the curing process was achieved, the foam was stripped from the mold and washed thoroughly with distilled water to remove excess non-reacted material. The drying process was completed in the oven at $80{ }^{\circ} \mathrm{C}$ for $8 \mathrm{~h}$. These steps were used for both untreated and treated kenaf bast/NRLF preparation and repeated without kenaf bast for preparing the control sample.

\section{Methods}

Fiber treatment

A $20 \%$ solution was made by dilution of $1 \%$ of Si- 69 by weight of the filler in ethanol. Next, filler was charged into a stand mixer and the solution was added slowly for uniform distribution of Si-69. The filler was continuously mixed for approximately $30 \mathrm{~min}$, followed by a drying process at $100{ }^{\circ} \mathrm{C}$ in an oven for approximately $5 \mathrm{~h}$ to allow complete the evaporation of the ethanol. 


\section{Measurement of tensile properties}

Tensile properties, such as tensile strength, tensile modulus, and elongation at break, were obtained by tensile tests using an Instron universal testing machine model 3366 (Instron, Norwood, MA, USA). Tests were conducted according to ASTM D412-06a (2006). Five dumbbell specimens of each kenaf loading for both untreated and treated kenaf bast/natural rubber latex foam were cut from molded sheets using a Wallace die cutter (GS Engineering Sdn Bhd, Klang, Selangor) and tests were performed at $25^{\circ} \mathrm{C}$. A crosshead speed of $250 \mathrm{~cm} \mathrm{~min}^{-1}$ was used.

\section{Compression test measurement}

Compression tests for the kenaf bast/NRLF were conducted using an Instron 3366 machine in accordance with ASTM D3574 (2003). The dimensions for the samples were $50 \mathrm{~mm} \times 50 \mathrm{~mm} \times 25 \mathrm{~mm}$. Tests were performed at $50 \mathrm{~mm} / \mathrm{min}$ speed and $25^{\circ} \mathrm{C}$. Five specimens for each loading were compressed until it reached $50 \%$ of their original thickness. The stress versus kenaf loading at 50\% compression was obtained.

\section{Compression set measurement}

Compression set measurements were evaluated according to ASTM D1055-97 (1997). Three specimens were used in this testing with the dimensions $50 \mathrm{~mm} \times 50 \mathrm{~mm} \times$ $25 \mathrm{~mm}$. The samples were compressed to $50 \%$ of their original thicknesses using two plates of compression devices. Compressed specimens were placed in the oven at $70{ }^{\circ} \mathrm{C}$ for $22 \mathrm{~h}$ along with the apparatus. After $22 \mathrm{~h}$, specimens were quickly removed from the apparatus. The thickness measurement was taken after a 30-min recovery. The recovery percentage was calculated according to Eq. 1:

$$
\text { Recovery }(\%)=\frac{\text { Final thickness of specimen }(\mathrm{mm})}{\text { Original thickness of specimen }(\mathrm{mm})} \times 100
$$

\section{Hardness}

The hardness test of kenaf bast/NRLF (Table 2) was conducted using the Foam and Sponge Rubber Durometer 302SL (PTC Instruments, Los Angeles, CA, USA) with sample dimensions of $55 \mathrm{~mm} \times 30 \mathrm{~mm} \times 25 \mathrm{~mm}$ (length $\times$ width $\times$ thickness).

Table 2. Foam and Sponge Rubber Durometer 302SL Value Ranges (Bashir et al. 2017)

\begin{tabular}{|c|c|}
\hline Class & Value Range \\
\hline X-Soft & 19 to 27 \\
\hline R32-Soft & 27 to 42 \\
\hline R33-Medium & 42 to 66 \\
\hline R34-Firm & 66 to 90 \\
\hline R35-Xfirm & 90 to 100 \\
\hline
\end{tabular}

\section{Swelling}

Samples of kenaf bast/NRLF were cut into dimensions of $30 \mathrm{~mm} \times 5 \mathrm{~mm} \times 2 \mathrm{~mm}$ and weighed. Then, samples were immersed in toluene. Samples were placed into a closed bottle and allowed to swell for $72 \mathrm{~h}$. After $72 \mathrm{~h}$, samples were removed, and surfaces of the swollen tested samples were wiped. Tested samples were weighed before the swelling percentage was calculated according to Eq. 2: 


$$
\text { Swelling }(\%)=\frac{\text { Swollen weight }- \text { Initial weight }(\mathrm{g})}{\text { Initial weight }(\mathrm{g})} \times 100
$$

\section{Fourier transform infrared (FTIR) spectroscopy}

Fourier transform infrared spectroscopy (Perkin Elmer System 2000; PerkinElmer Inc., Waltham, MA, USA) was used to detect chemical changes in tested samples. Wavenumbers used to record FTIR spectra were within the range of 550 to $4000 \mathrm{~cm}^{-1}$ with an average of 24 scans.

\section{Scanning electron microscopy (SEM)}

Scanning electron microscopy (TM100; Hitachi Ltd., Chiyoda-ku, Tokyo) analysis was performed to study the surface morphology of both untreated and treated kenaf bast/natural rubber latex foam. The foam surfaces were sputter-coated with a thin layer of gold using a Polaran SC 515 sputter coater (Bio-rad, Hercules, CA, USA) to avoid electrostatic charging and poor image resolution during testing. The comparison of pore morphologies and rubber-filler adhesion for both untreated and treated kenaf bast/NRLF was observed.

\section{RESULTS AND DISCUSSION}

\section{Tensile Properties}

Figure 1 displays tensile strength of natural rubber latex foam (NRLF). As shown, tensile strength dropped as soon as filler was added at 1 pphr. A similar observation was reported by Borkar et al. (2007), that the tensile strength of the control sample without filler showed higher tensile value compared to the filled sample. The trend consistently dropped as more filler was added at higher filler loading. This was because the presence of filler required more surface to be wetted by the matrix. An empty gap between spaces full of fillers could occur. This leads to ineffective contact between filler and matrix. The reduction in the effectiveness of filler-matrix interaction caused insufficiency in creating bonding between filler and matrix. As a result, ineffective stress transfer in the system reduced the tensile strength (Fairuz et al. 2016). However, higher value of tensile strength for treated sample at the same filler loading compared to control sample was due to improvement of filler-matrix adhesion. This advantage indicate the effectiveness of silane coupling agent to improved compatibility between filler and matrix.

Moreover, as filler loading increases, the fillers tend to agglomerate to each other. This can be explained by considering the kenaf bast structure. Kenaf bast has a fibrous shape that is easy to agglomerate at high filler loading. According to Akil et al. (2011), the main obstacle in using kenaf fiber as filler reinforcement in composites is the difficulties in manually separating and visually dispersing it evenly in the course of manufacturing. The agglomeration creates a high stress concentration area that prevents effective stress transfer in the system. Thus, tensile strength reduced with increment of filler loading.

As more filler was added, the amount of porosity in foam increased (Borkar et al. 2007). As discussed earlier, the agglomeration happened at higher filler content and sizes of pores will increase, which will also lead to the reduction of wettability between filler within the matrix and reduced tensile. Tensile strength of both untreated and treated samples show lowest tensile strength value at highest filler loading ( $7 \mathrm{pphr}$ ) due to filler agglomeration. This result will be support by SEM image later. 
Generally, the higher the value of tensile strength, the better the performance of the material (Fairuz et al. 2016). Based on Fig. 1, tensile strength of treated kenaf bast/NRLF showed higher value than the untreated sample. This phenomenon occurs due to the presence of silane, which enhanced wettability of kenaf by the matrix. Without a coupling agent, the only adhesion mechanism is interdiffusion (Rao et al. 2018). The presence of a silane-coupling agent enhanced the formation of hydrogen and covalent bonding between the hydroxyl groups of filler and polysiloxanes through hydrogenation of silanes. This provide better adhesion between the fiber and the matrix. Increment of tensile strength after silane treatment due to better adhesion can be explained by the improvement of stress transfer through fiber. Abdul Wahab and Husseinshah (2018) reported a similar observation in their study on the effect of modified filler surface with a silane coupling agent on mechanical properties of unsaturated polyester composite. Composite added with chemically modified filler showed higher tensile strength compared to composite obtained without the chemical modification.

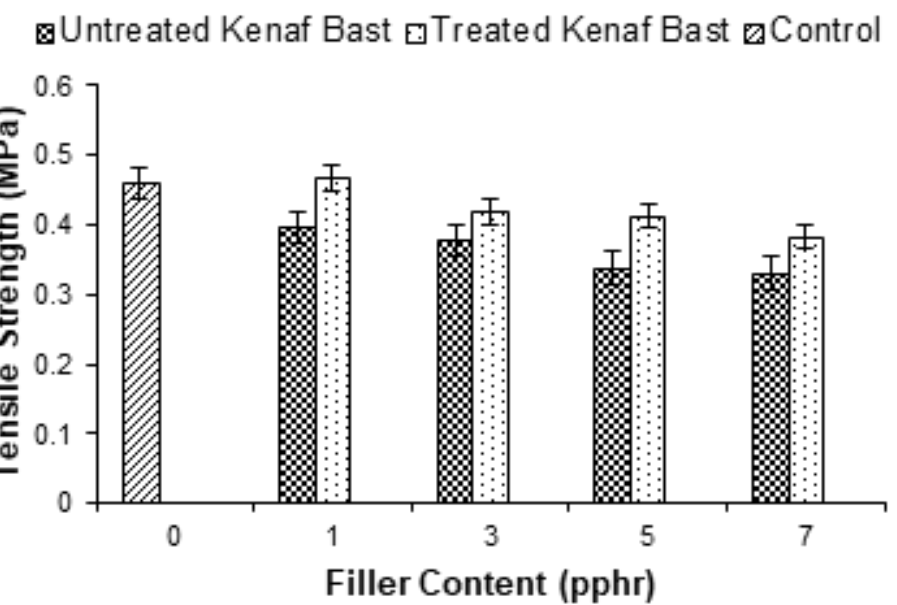

Fig. 1. Tensile strength of kenaf bast-filled foam versus filler content and comparison between untreated and treated kenaf bast/NRLF

Figure 2 depicts that elongation at break gradually decreased as the filler content increased. The elongation at break value started to drop after filler addition at $1 \mathrm{pphr}$. Theoretically, the behavior of composite changed from ductile to brittle at high filler loading (Fu et al. 2008). The presence of filler in flexible rubber chains caused a restriction to the matrix mobility. Thus, the more filler added into the matrix, it tended to be difficult to have greater elongation.

The result of elongation at break of both treated and untreated kenaf bast/NRLF at the same filler content are compared in Fig. 2. Elongation at break was reduced further as treated kenaf was added into the foam. Better bonding between filler and matrix reduced the elasticity, resulting in more stiff and rigid composites. Silane as a bifunctional coupling agent acts as a bridge to allow polar matrix and nonpolar filler to be coupled together (Pickering et al. 2015). On elongation, the strong bonding prevents filler from sliding easily within the matrix. This leads to lower resistance to break. Pang et al. (2018) reported lower elongation at break of the treated kenaf filled composite than that of the untreated kenaf filled composite as it had reduced ductility in the composite due to better interfacial adhesion. 


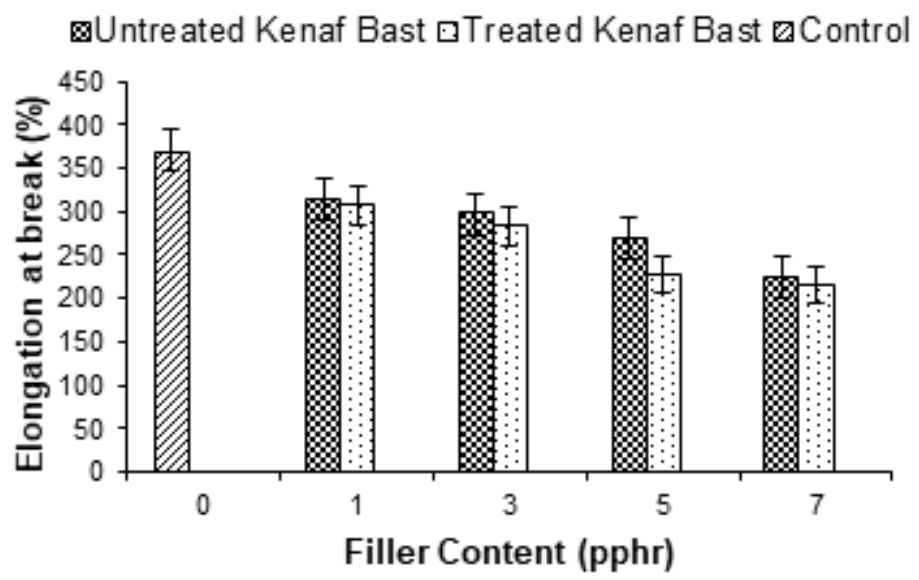

Fig. 2. Elongation at break of kenaf bast-filled foam versus filler content and comparison between untreated and treated kenaf bast/NRLF

The trend of modulus at $100 \%$ elongation (M100) versus filler content for kenaf bast/NRLF can be seen in Fig. 3. Modulus (M100) increased linearly with increment of filler into the foam because of high rigidity. High loading of filler required high force to stretch specimens to the given percent of elongation (100\%). Moreover, the viscosity of the matrix increased after the filler addition. A high viscous matrix will increase the amount of energy to cleave chain-chain and chain-filler attachments (Tugau 2010).

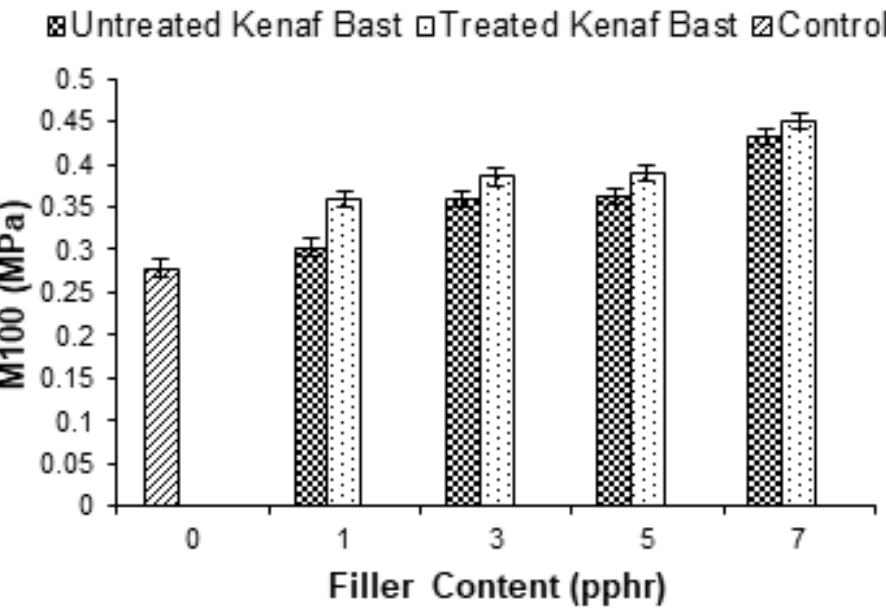

Fig. 3. Modulus at $100 \%$ elongation (M100) of kenaf bast-filled foam versus filler content and comparison between untreated and treated kenaf bast/NRLF

Based on Fig. 3, M100 was higher with the addition of treated kenaf bast into NRLF compared to untreated kenaf bast foam. This is because of the reduction of incompatibility between fibers and rubber matrix by the silane coupling agent that resulted in better adhesion between the filler and matrix, thus increasing the rigidity (Cao et al. 2014). The formation of chemical bonding between fiber and NRL matrix through chemical reactions is illustrated in Fig. 4. Bis-(3-triethoxysilylpropyl) tetrasulphane (Si-69) contains ethoxy hydrolysable groups at both ends that enable the silicon groups to bond with kenaf fibres and the tetrasulphane group of its centre will bond with natural rubber latex matrix. 


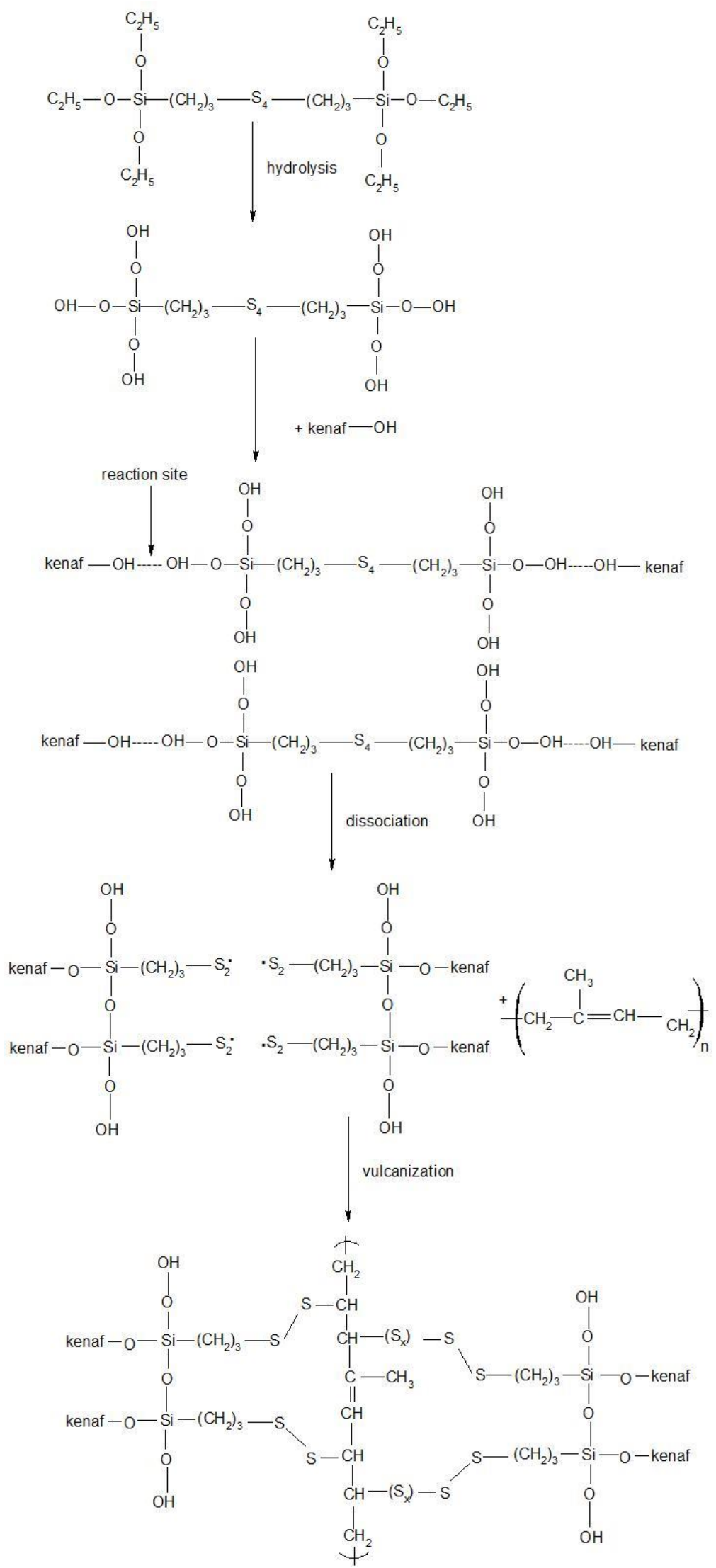

Fig. 4. Possible reaction between silane coupling agent (Si-69) with kenaf bast and NR 
Kenaf fibres has $\mathrm{OH}$ groups on their surface, which have the potential to be the reactive sites. Thus, natural rubber latex interaction with kenaf will be improved by using Si-69 (Khimi and Pickering 2016). As a result, a solid interfacial layer was greatly enhanced between the two phases. Kenaf fiber was tightly cross-linked between the two phases, thus increasing the stiffness of the treated samples. Figure 4 shows the possible reaction between the silane coupling agent (Si-69) with kenaf bast and NR.

\section{Compression Test}

Figure 5 exhibits the compression test at $50 \%$ strain values versus the loading of kenaf bast. The values of stress increased as the filler loadings increased. Higher filler loading required a higher amount of force for compression at $50 \%$ strain of kenaf bastfilled foams. As a result, higher stiffness of the foams was produced. At the same filler loadings, the values of stress of treated and untreated kenaf bast/NRLF was compared. Again, due to better rubber-filler adhesion, treated kenaf bast foam showed higher stress values compared to untreated kenaf bast-filled foam.

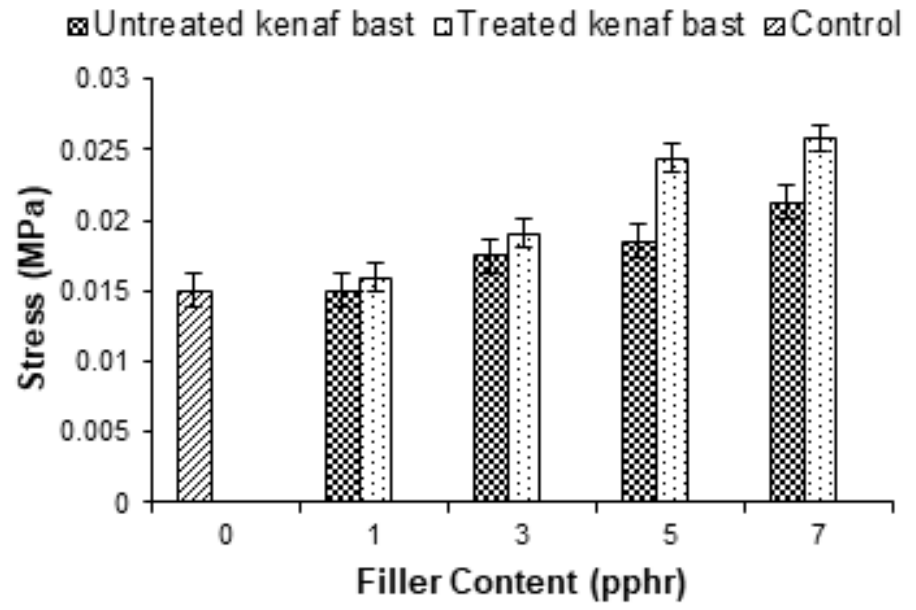

Fig. 5. Compression test at $50 \%$ strain of kenaf bast-filled foam versus filler content and comparison between untreated and treated kenaf bast/NRLF

\section{Hardness}

Hardness of the kenaf bast/NRLF at different filler loadings is shown in Fig. 6. The hardness value for all foam samples was within a range of 70 to 85, which is in the range of R34-Firm (Bashir et al. 2017). Based on Fig. 6, higher kenaf loadings resulted in increases of hardness. Higher kenaf loadings caused the filler to form aggregates, which constrained the mobilization of filler in NRLF and led to the decreasing of flexibility and elasticity of rubber chain. Thus, the stiffness of the NRLF increased resulting from increment of hardness.

The results also showed higher values of hardness for treated-kenaf bast/NRLF than untreated-kenaf bast/NRLF. Silane treatment on kenaf surfaces did improve hardness of composite due to better interfacial adhesion between the fiber and matrix polymer. Using the silane coupling agent, the chemical reaction took place and connected the chains. The rubbery matrix became less elastic and more rigid. Thus, high resistance to elastic deformation surface occurred. The result obtained agreed with previous work by Nishitani et al. (2017), who reported higher hardness value of treated hemp fiber (HF) reinforced plant-derived polyamide 1010 (PA1010) biomass composite compared with the untreated sample. 


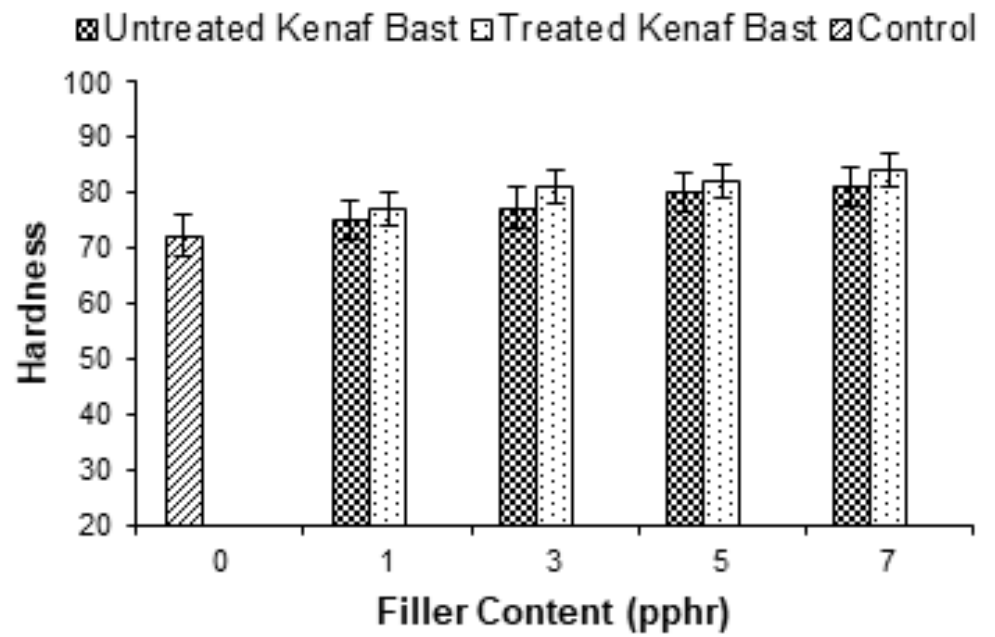

Fig. 6. Hardness of kenaf bast-filled foam versus filler content and comparison between untreated and treated kenaf bast/NRLF.

\section{Swelling}

The trend of swelling percentage of kenaf bast-filled foams at different filler content is shown in Fig. 7. Swelling percentage was decreased for both treated and untreated kenaf bast-filled NRLF with increment of kenaf loading due to high volumefraction of filler. This is because filler particles can act as obstacles for penetration of toluene into the rubber matrix. As shown, swelling percentage of treated samples resulted in lower value compared with untreated samples. This is because of more crosslinking structure formed led to reduction the free spaces for toluene to penetrate into the foam. The same observation was reported by Ho et al. (2015); EVA/NR/PF silane $_{\text {composites showed }}$ lower mass swell percentage in comparison with EVA/NR/PF composites as free volume for toluene to penetrate were limited.

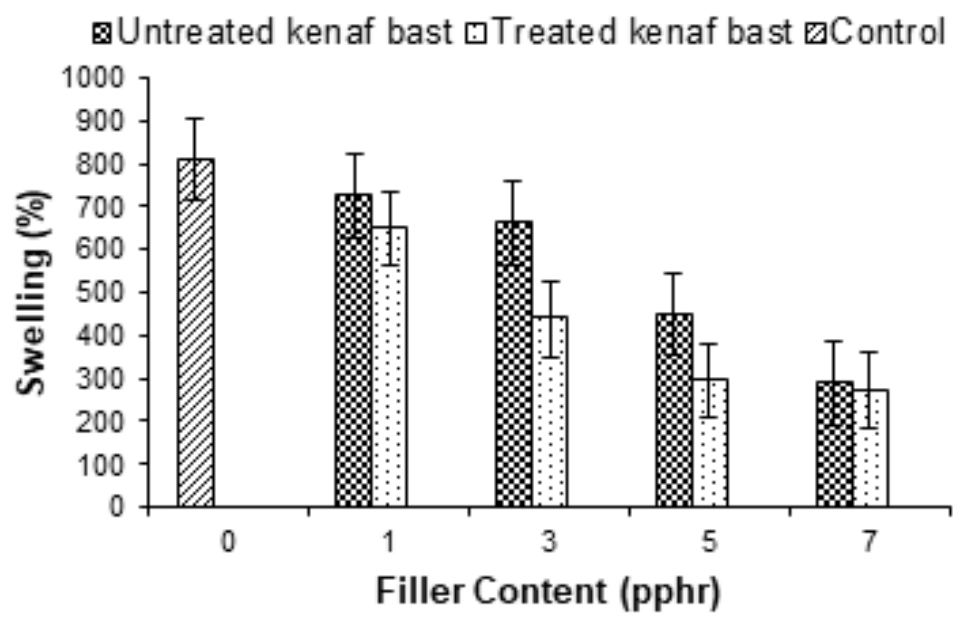

Fig. 7. Swelling percentage of kenaf bast-filled foam versus filler content and comparison between untreated and treated kenaf bast/NRLF. 


\section{Compression Set}

Figure 8 shows recovery percentage for both treated and untreated kenaf bast-filled foams versus the loading of kenaf bast. The results showed a decrease of recovery percentage with an increase of kenaf loading for both treated and untreated kenaf bastfilled NRLF due to a more broken molecular chain. The recovery percentage value after addition of filler at $1 \mathrm{pphr}$ was lower than the control sample. This shows that the foam was better to resist permanent deformation after prolonged compressive stresses at a given temperature and deflection with the help of filler due to high stiffness.

However, small differences in recovery percentage between treated and untreated samples can be seen in Fig. 8. Treated samples show small difference of values in recovery percentage $(82.52 \%, 81.23 \%, 81.2 \%$, and $80.52 \%)$ compared to untreated samples $(82.64 \%, 81.52 \%, 81.43 \%$, and $80.99 \%)$ at the same filler loading. This observation indicated that silane treatment of kenaf did not affect the compression set of kenaf bastfilled NRLF.

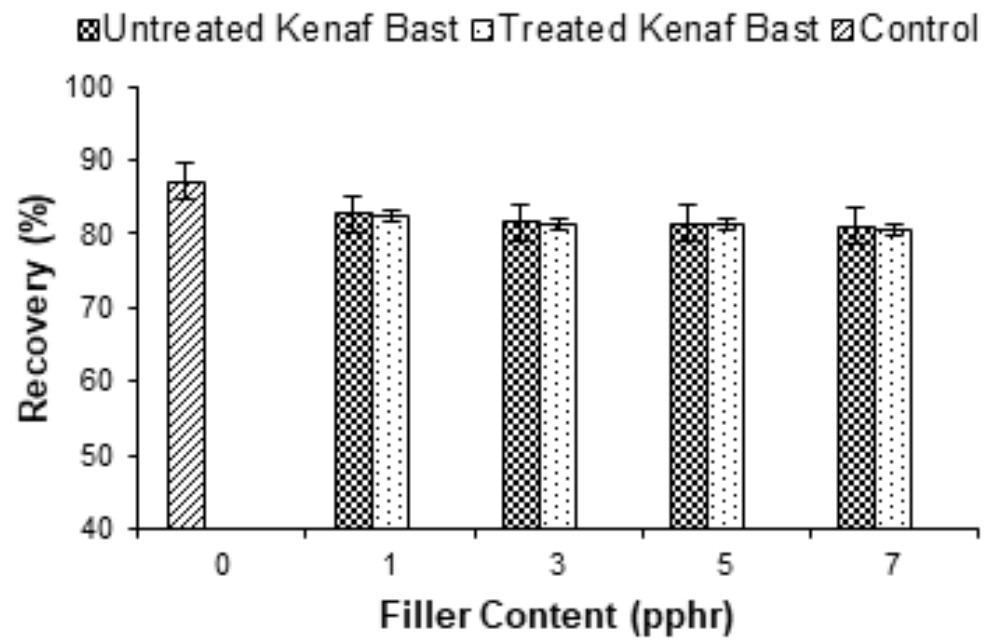

Fig. 8. Recovery percentage for both treated and untreated kenaf bast/NRLF versus filler content

\section{FTIR Analysis}

The results of FTIR analysis of both treated and untreated kenaf bast/NRLF are depicted in Fig. 9 to determine the presence of the silanol group and the stretching of peaks due to the silane treatment. Figure 9(a) represents the untreated kenaf bast/NRLF, while Fig. 9(b) represents the silane-treated kenaf bast/NRLF.

Formation of broad bands within the range of 3300 to $3500 \mathrm{~cm}^{-1}$ represented O-H stretching of Si-OH. An absorption peak can be detected at $1017 \mathrm{~cm}^{-1}$, attributed to $\mathrm{Si}-\mathrm{O}$ stretching of Si-OH (Xu et al. 2007). Other characteristic peaks were found in the range of 2800 to $3000 \mathrm{~cm}^{-1}$ for both treated and untreated kenaf bast/NRLF, which can be attributed to aliphatic alkyl group (C-H) stretching of $-\mathrm{CH}_{2}$ (Xu et al. 2007). However, the infrared band at $2855 \mathrm{~cm}^{-1}$ increased in intensity for the treated sample $\left(2925 \mathrm{~cm}^{-1}\right)$, which indicated improvement of reaction as increasing in chain length (Coates 2006). Thus, better interaction between kenaf filler and the rubber matrix by silane treatment can be demonstrated from the formation of these bonds. 


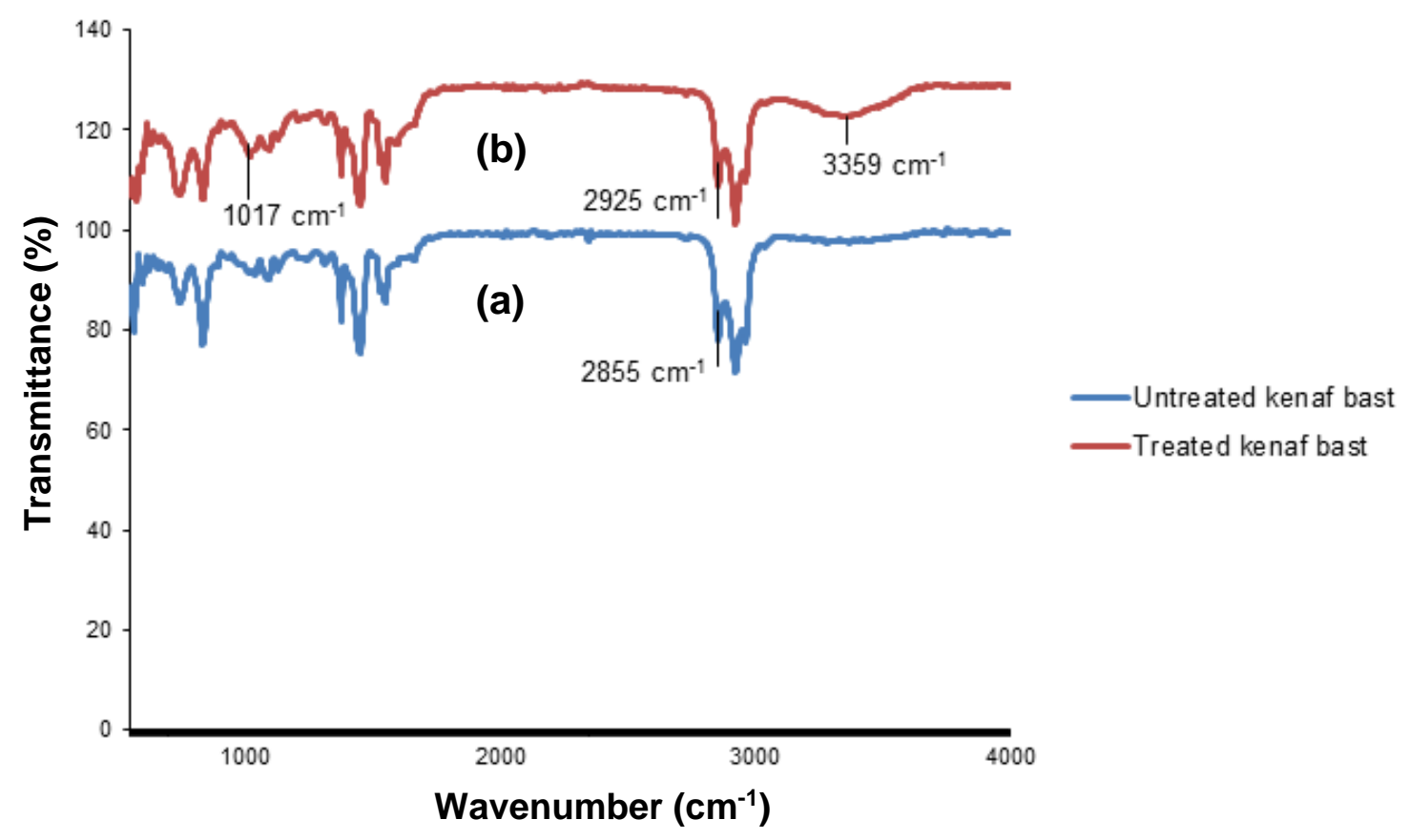

Fig. 9. FTIR spectrum kenaf bast/NRLF: (a) without silane treatment and (b) with silane treatment at $7 \mathrm{pphr}$ of kenaf bast/NRLF

\section{Surface Morphology Study}

Figure 10 represents the influence of treated kenaf incorporation on morphologies of kenaf bast/NRLF. From Fig. 10a and Fig. 10b, both samples clearly show open cell structures.

A similar observation was reported by Roslim et al. (2012), who found that foam structure is made of continuous interconnecting open cells, based on SEM imaging. When a comparison is made, it can be seen that the sample with treated kenaf (Fig. 10b) showed small pores and stable sizes $(170 \mu \mathrm{m}, 184 \mu \mathrm{m}$ and $187 \mu \mathrm{m})$ of cell structures compared with the sample with untreated kenaf (Fig. 10a) with measurements $137 \mu \mathrm{m}, 226 \mu \mathrm{m}$ and $285 \mu \mathrm{m}$. This showed that the addition of treated kenaf to the system reduced the pore size and gave better cell structures to the latex foam.

Filler-matrix interaction of untreated and treated kenaf bast/NRLF at $7 \mathrm{pphr}$ kenaf loading was observed in Fig. 10c and Fig. 10d. From Fig. 10c it can be seen that the sample with untreated kenaf showed that a gap was built between the filler and matrix, thus indicating weak filler-matrix interaction. By contrast, the sample with treated kenaf in Fig. 10(d) showed better filler-matrix interaction, which led to the improvement in tensile properties.

This observation demonstrated the higher tensile strength of treated samples that was discussed earlier. In Fig. 10e, filler agglomeration can be spotted in several places at $7 \mathrm{pphr}$ kenaf loading which support result of tensile strength that decreased as filler loading increased. 


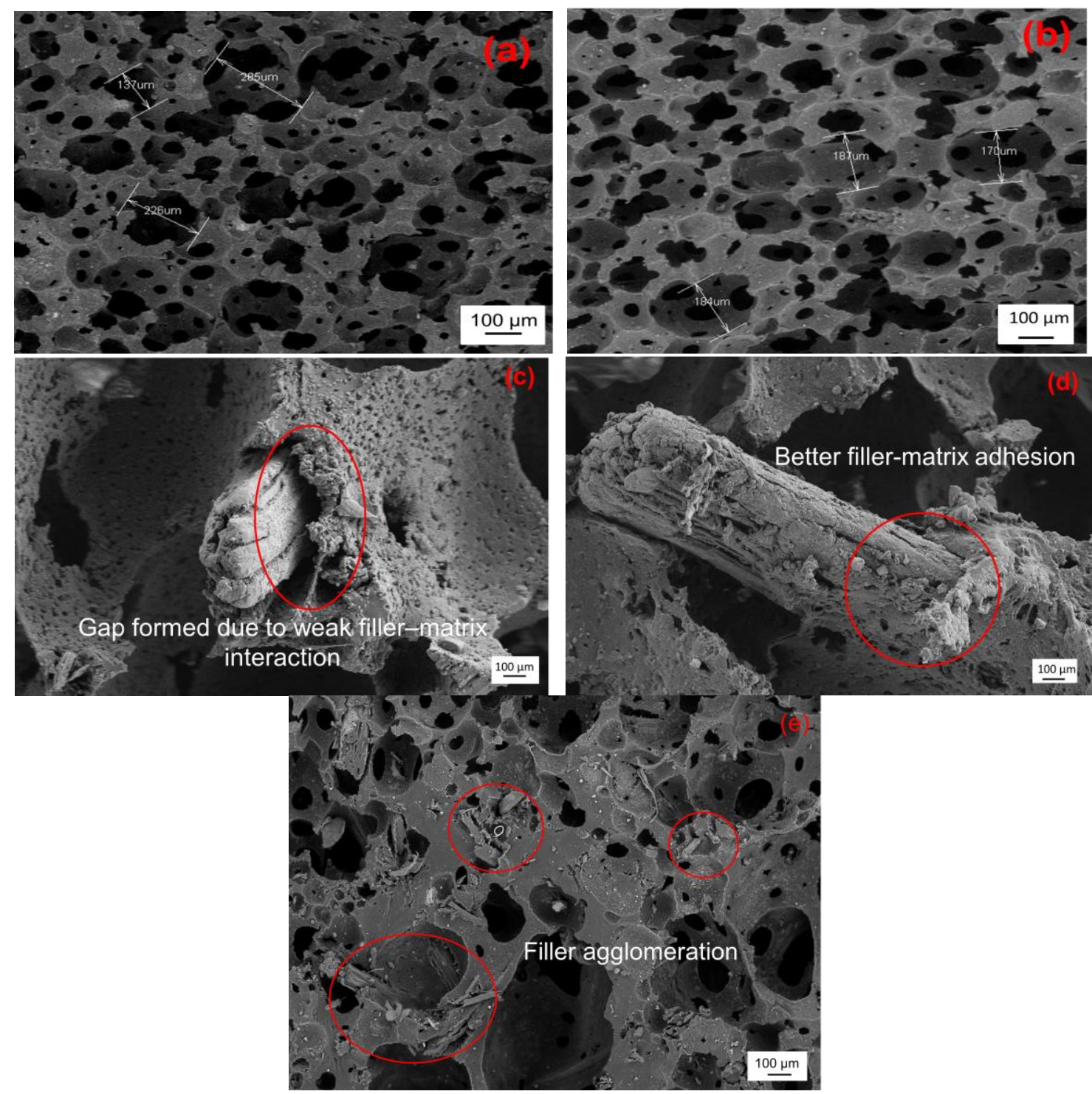

Fig. 10. (a) Untreated kenaf bast/NRLF at $100 \times$ magnification, (b) treated kenaf bast/NRLF at 100x magnification, (c) untreated kenaf bast/NRLF at $7 \mathrm{pphr}$ of $500 \mathrm{x}$ magnification, (d) treated kenaf bast/NRLF at 7 pphr of 500x magnification, and (e) filler agglomeration at $7 \mathrm{pphr}$ of kenaf bast/NRLF at 120x magnification

\section{CONCLUSIONS}

1. Kenaf bast loading had the greatest influence on modulus at $100 \%$ elongation (M100), compression strength, and hardness. Increasing kenaf bast loading increased M100, compression strength, and hardness values.

2. However, tensile strength, elongation at break, and the swelling and recovery percentages decreased as the kenaf bast loading increased.

3. For the effect of silane treatment on properties of natural rubber latex foam (NRLF), treated NRLF showed higher value in tensile strength, hardness, and compression 
strength compared to untreated NRLF. The reverse effect was shown for elongation at break, swelling and recovery percentage.

4. Better contact at filler-matrix interfaces was apparent from SEM images, which is consistent with improved adhesion of treated NRLF to the matrix.

5. The presence of the silanol group and stretching peaks due to silane treatment was obtained by FTIR analysis.

\section{ACKNOWLEDGMENTS}

The authors are grateful for the support of the Fundamental Research Grant Scheme (FRGS) under grant number '203.PBahan.6071375' from the Ministry of Education Malaysia.

\section{REFERENCES CITED}

Akil, H. M., Omar, M. F., Mazuki, A. A. M., Safiee, S., Ishak, Z. A. M., and Bakar, A. A. (2011). "Kenaf fiber reinforced composites: A review," Mater. Design 32(8-9), 41074121. DOI: 10.1016/j.matdes.2011.04.008

Ariff, Z. M., Zakaria, Z., Tay, L. H., and Lee, S. Y. (2008). "Effect of foaming temperature and rubber grades on properties of natural rubber foams," J. Appl. Polym. Sci. 107(4), 2531-2538. DOI: 10.1002/app.27375

ASTM D412-06a (2006). "Standard test methods for vulcanized rubber and thermoplastic elastomers-tension" ASTM International, West Conshohocken, PA, USA.

ASTM D1055-97 (1997). "Standard test method for flexible cellular materials-latex, foam," ASTM International, West Conshohocken, PA, USA.

ASTM D3574-03 (2003). "Standard test method for flexible cellular materials-slab, bonded and molded urethane foams," ASTM International, West Conshohocken, PA, USA.

Bashir, A. S. M., Manusamy, Y., Chew, T. L., Ismail, H., and Ramasamy, S. (2017). "Mechanical, thermal, and morphological properties of (eggshell powder)-filled natural rubber latex foam," J. Vinyl Addit. Techn. 23(1), 3-12. DOI: 10.1002/vnl.21458

Borkar, S. P., Kumar, S., and Mantha, S. S. (2007). "Effect of silica and calcium carbonate fillers on the properties of woven glass fibre composites," Indian J. Fibre. Text. 32(2), 251-253.

Cao, X. V., Ismail, H., Azura, A. R., and Takechi, T. (2014). "Effect of filler surface treatment on the properties of recycled high-density polyethylene/(natural rubber)/(kenaf powder) biocomposites," J. Vinyl. Addit. Techn. 20(4), 218-224. DOI: $10.1002 / \mathrm{vnl} .21374$

Coates, J. (2006). "Interpretation of infrared spectra, a practical approach," in: Encyclopedia of Analytical Chemistry, R. A. Meyers, and M. L. McKelvy (eds.), John Wiley \& Sons, Hoboken, NJ, USA, pp. 4-5. DOI: 10.1002/9780470027318.a5606

Fairuz, A. M., Sapuan, S. M., Zainudin, E. S., and Jaafar, C. N. A. (2016). "Effect of filler loading on mechanical properties of pultruded kenaf fibre reinforced vinyl ester 
composites," J. Mech. Eng. Sci. 10(1), 1931-1942. DOI:

10.15282/jmes.10.1.2016.16.0184

Fu, S. -Y., Feng, X.-Q., Lauke, B., and Mai, Y.-W. (2008). "Effects of particle size, particle/matrix interface adhesion and particle loading on mechanical properties of particulate-polymer composites," Compos. Part B-Eng. 39(6), 933-961. DOI: 10.1016/j.compositesb.2008.01.002

Hao, L. C., Sapuan, S. M., Hassan, M. R., and Sheltami, R. (2018). "Natural fiber reinforced vinyl polymer composites," in: Natural Fibre Reinforced Vinyl Ester and Vinyl Polymer Composites, Elsevier, Amsterdam, Netherlands, pp. 27-70. DOI: 10.1016/B978-0-08-102160-6.00002-0

Ho, S. H., Supri, A. G. and Ismail, H. (2015). "Enhancing interfacial adhesion of potash feldspar with silane (Si-69) coupling agent on properties of ethylene vinyl acetate (EVA)/ natural rubber (NR)/ potash feldspar composites," Journal of Advanced Research in Materials Science 11(1), 8-19.

Huo, S., Chevali, V. S., and Ulven, C. A. (2013). "Study on interfacial properties of unidirectional flax/vinyl ester composites: Resin manipulation on vinyl ester system," J. Appl. Polym. Sci. 128(5), 3490-3500. DOI: 10.1002/app.38565

Ismail, H., Mega, L., and Abdul Khalil, H. P. S. (2001). "Effect of a silane coupling agent on the properties of white rice husk ash-polypropylene/natural rubber composites," Polym. Int. 50(5), 606-611. DOI: 10.1002/pi.673

Kamal, I. B. (2014). "Kenaf for biocomposite: An overview," J. Sci. Technol. 6(2), 4166.

Karim, A. F. A., Ismail, H., and Ariff, Z. M. (2018). "Effects of kenaf loading and alkaline treatment on properties of kenaf filled natural rubber latex foam," Sains Malays. 47(9), 2163-2169. DOI: 10.17576/jsm-2018-4709-26

Khimi, S. R. and Pickering, K. L. (2016). "The effect of silane coupling agent on the dynamic mechanical properties of iron sand/ natural rubber magnetorheological elastomers," Composites Part B: Engineering 90, 115-125. DOI: 10.1016/j.compositesb.2015.11.042

Kuthi, F. A. A., Yunus, N. M., Horng, G. K., and Badri, K. H. (2018). "Determination of glucose contents in kenaf," Malaysian Journal of Analytical Sciences 22(6), 10481056. DOI: 10.17576/mjas-2018-2206-15

Lee, B.-H., Kim, H.-S., Lee, S., and Kim, H.-J. (2009). "Bio-composites of kenaf fibers in polylactide: Role of improved interfacial adhesion in the carding process," Compos. Sci. Technol. 69(15-16), 2573-2579. DOI: 10.1016/j.compscitech.2009.07.015

Nishitani, Y., Kajiyama, T., and Yamanaka, T. (2017). "Effect of silane coupling agent on tribological properties of hemp fiber-reinforced plant-derived polyamide 1010 biomass composites," Materials 10(9), Article Number 1040. DOI: 10.3390/ma10091040

Pang, A. L., Ismail, H., and Bakar, A. A. (2018). "Eco-friendly coupling agent-treated kenaf/linear low-density polyethylene/poly(vinyl alcohol) composites," Iran. Polym. J. 27(2), 87-96. DOI: 10.1007/s13726-017-0588-z

Pickering, K. L., Khimi, R., and Ilanko, S. (2015). "The effect of silane coupling agent on iron sand for use in magnetorheological elastomers Part 1: Surface chemical modification and characterization," Compos. Part A-Appl. S. 68, 377-386. DOI: 10.1016/j.compositesa.2014.10.005 
Ramasamy, S., Ismail, H., and Manusamy, Y. (2013). "Effect of rice husk powder on compression behaviour and thermal stability of natural rubber latex foam," BioResources 8(3), 4258-4269. DOI: 10.15376/biores.8.3.4258-4269

Rao, J., Zhou, Y., and Fan, M. (2018). "Revealing the interface structure and bonding mechanism of coupling agent treated WPC," Polymers-Basel 10(3), Article Number 266. DOI: $10.3390 /$ polym 10030266

Rathnayake, I., Ismail, H., Azahari, B., and Bandara, I. M. C. C. D. (2014).

"Enhancement of the antibacterial activity of natural rubber latex foam by the incorporation of zinc oxide nanoparticles," J. Appl. Polym. Sci. 131(1), Article ID 39601. DOI: 10.1002/app.39601

Roslim, R., Hashim, M. Y. A., and Augorio, P. T. (2012). "Natural latex foam," J. Eng. Sci. 8, 15-27.

Saheb, D. N., and Jog, J. P. (1999). "Natural fiber polymer composites: A review," Adv. Polym. Tech. 18(4), 351-363. DOI: 10.1002/(SICI) 1098-2329 (199924)18:4

Tran, T., Bénézet, J.-C., and Bergeret, A. (2014). "Rice and Einkorn wheat husks reinforced poly(lactic acid) (PLA) biocomposites: Effects of alkaline and silane surface treatments of husks," Ind. Crop. Prod. 58, 111-124. DOI: 10.1016/j.indcrop.2014.04.012

Tugau, A. J. (2010). The Effect of Filler Loading on the Tensile Strength of Natural Rubber Compound, Master's Thesis, Universiti Malaysia Pahang, Pahang, Malaysia.

Wahab, N. M. A., and Husseinshah, S. (2018). "The influence of filler loading and the chemically-modified filler surface on the mechanical properties of palm kernel shell reinforced polyester composites," Adv. Mater. Res-Switz. 25(2), 71-78.

$\mathrm{Xu}, \mathrm{H}$., Liu, J., Fang, L., and Wu, C. (2007). "In situ grafting onto silica surface with epoxidized natural rubber via solid state method," J. Macromol. Sci. B. 46(4), 693703. DOI: $10.1080 / 00222340701388854$

Article submitted: January 3, 2020; Peer review completed: March 12, 2020; Revised version received: August 10, 2020; Accepted: October 11, 2020; Published: October 28, 2020.

DOI: $10.15376 /$ biores.15.4.9507-9522 